\title{
Identification of mutations that encode drug resistance in the polymerase gene of the human immunodeficiency virus
}

\author{
ZHENGXIAN Gu MD, HengSHENG FANG MD, HORACIO SALOMON PhD, QING GAO MD, \\ MARK A WAINBERG PhD
}

\begin{abstract}
$Z$ Gu, H Fang, H SAlOmon, Q Gao, MA WAINBERG. Identification of mutations that encode drug resistance in the polymerase gene of the human immunodeficiency virus. Can $J$ Infect Dis 1994;5(Suppl E):29E-33E. In vitro selection in MT-4 cells was used to generate human immunodeficiency virus-type 1 (HIV-1) variants that are resistant to $2^{\prime}, 3^{\prime}$-dideoxycytidine (ddC), $2^{\prime}, 3^{\prime}$-dideoxyinosine (ddI) and the (-) enantiomer of $2^{\prime}, 3^{\prime}$-dideoxy-3'-thiacytidine (3TC). The complete reverse transcriptase open reading frames of these viruses, and portions of flanking protease and integrase within the pol gene, were cloned and sequenced by polymerase chain reaction (PCR) techniques. Mutations were observed at each of amino acid sites 65 (Lys $\rightarrow$ Arg; AAA $\rightarrow$ AGA) and $184($ Met $\rightarrow$ Val; ATG $\rightarrow$ GTG) when ddC was used in this protocol, and at site 184 only when either $3 \mathrm{TC}$ or ddI was employed. These mutations were introduced into the pol gene of infectious recombinant HXB2-D DNA by site-directed mutagenesis to confirm, by viral replication assay, their importance in conferring resistance against these drugs. A recombinant virus containing the site 65 mutation only possessed greater than 10-fold resistance against ddC compared with parental HXB2-D. Moreover, cross-resistance of about 20-fold and threefold, respectively, was detectable against 3TC and ddI but not against 3 '-azido-3'-deoxythymidine (AZT). When the 65 and 184 mutations were combined into HXB2-D, the resultant construct did not possess higher levels of resistance to any of these drugs than observed with the site 65 or 184 mutation alone. These mutations were further demonstrated by PCR analysis of peripheral blood mononuclear cells from 10 patients on long term ddC therapy, although variable patterns were observed in terms of which of the two mutations or both were present. Sometimes, the wild-type site 65 codon was also detected, indicating the presence of mixtures of viral quasi-species. Direct cloning and sequencing revealed the site 65 mutation in viruses isolated from patients on prolonged ddC therapy. (Pour résumé, voir page 30E)
\end{abstract}

Key Words: 3TC, AZT, ddC, ddI, Human immunodeficiency virus-type 1, Resistance

Lady Davis Institute-Jewish General Hospital and McGill University AIDS Centre, Montreal, Quebec

Correspondence and reprints: Dr Zhengxian Gu, McGill University AIDS Centre, Jewish General Hospital, 3755 Chemin Côte Ste-Catherine, Montreal, Quebec H3T 1E2 


\section{Identification des mutations codant la résistance aux médicaments dans le gène de la polymérase du virus de l'immunodéficience humaine}

RÉSUMÉ : La sélection in vitro de cellules MT-4 devait générer des variantes du virus de l'immunodéficience humaine de type 1 ( $\mathrm{VIH}-1)$ qui soient résistantes à la $2^{\prime}, 3^{\prime}$-didéoxycytidine (ddC), à la $2^{\prime}, 3^{\prime}$-didéoxyinosine (ddI) et à l'énantiomère de la 2',3'-didéoxy-3'-thiacytidine (3тс). Les cadres de lecture ouverts des transcriptases inverses complètes de ces virus et les portions des protéases avoisinantes et de l'intégrase à l'intérieur du gène pol ont été clonés et mis en séquence à laide de techniques de réactions de polymérisations en chaîne (PCR). Des mutations ont été observées pour chaque site des acides aminés 65 (Lys $\rightarrow$ Arg; AAA $\rightarrow$ AGA) et 184 (Met $\rightarrow$ Val; ATG $\rightarrow$ GTG) lorsque le ddC a été utilisé dans ce protocole et au site 184 . seulement lorsque soit le 3 TC ou le ddI ont été employés. Ces mutations ont été introduites dans le gène pol de l'ADN recombinant HXB2-D par une mutagenèse dirigée selon la localisation afin de confirmer par rêplication virale leur efficacité à conférer une résistance à l'endroit de ces médicaments. Un virus recombinant renfermant une mutation au site 65 ne possédait qu'une résistance décuplée à l'endroit du ddC en comparaison avec le HXB2-D parental. De plus, une résistance croisée multipliée par des facteurs de 20 et de 3 respectivement a été décelée à l'endroit du 3TC et du ddI et non pas à l'endroit de la 3'-azido-3'-déoxythimidine (AZT). Lorsque les mutations 65 et 184 ont été combinées au HXB2-D, la structure résultante ne s'est pas révélée posséder des taux de résistance à l'un ou l'autre de ces médicaments plus élevés que ceux observés aux sites 65 et 184 des mutations seules. Ces mutations ont en outre été confirmées par analyse PCR des cellules sanguines mononucléaires périphériques de 10 patients sous traitement prolongé par ddC, bien qu'une certaine variabilité ait été observée quant à la présence de l'une ou de l'autre ou encore des deux mutations. Parfois, un codon du site 65 de type sauvage a également êté décelé, indiquant la présence de mélanges de quasi-espèces virales. Le clonage direct et le séquençage ont révélé des mutations au site 65 dans des virus isolés de patients sous traitement prolongé par ddC.

$\mathrm{D}$ RUG-RESISTANT VARIANTS OF HIV ARE COMMONLY PREsent in the circulation of patients receiving prolonged chemotherapy with nucleoside compounds that block viral reverse transcriptase (RT) activity (1-3). Resistant HIV variants can also be selected in tissue culture by gradually increasing the concentrations of antiviral drugs in the medium $(4,5)$. Resistance has also been demonstrated against non-nucleoside antagonists of viral RT $(6,7)$. Although the appearance of drug-resistant viruses may be predictive of clinical progression, it is still unclear whether treatment failure is causally related to the emergence of viral drug resistance (8-10).

Nucleoside antagonists of the HIV RT act by blocking the synthesis of proviral DNA (11). Since the HIV RT is error-prone, mutations occur frequently in the viral genome during replication (12). Thus, mutations that confer drug resistance are amplified under drug pressure. Mutations in the pol genes of HIV-1 strains that are resistant to 3'-azido-3'-deoxythymidine (AZT) (13), 2', 3'dideoxyinosine (ddI) $(3,14), 2^{\prime}, 3^{\prime}$-dideoxy-3'-thiacytidine (3TC) $(15,16)$ and $2^{\prime}, 3^{\prime}$-dideoxycytidine (ddC) (17) have been identified.

ddC has been used extensively to treat HIV-infected individuals who are intolerant to either AZT or ddI; it is also used in combination with AZT to try to prevent or delay the development of drug resistance (18). ddI is being used increasingly to treat patients who have previously received AZT for one year or more, and 3TC is a promising drug now in clinical trials. It is important to ask whether these compounds will be likely to encounter problems of drug resistance and to identify the mutation sites responsible. This paper reports on novel mutations at sites 65 and 184 of the HIV-1 RT that confer resistance against both $\mathrm{ddC}$ and $3 \mathrm{TC}$, and to a lesser extent against ddI, depending on the type of host cell employed in the drug sensitivity analysis.

\section{MATERIALS AND METHODS}

Cells and viruses: MT-4 cells were used to propagate both wild-type and resistant variants of HIV-1 in suspension culture in RPMI-1640 medium (Gibco Laboratories). supplemented with $2 \mathrm{mM} L$-glutamine, $100 \mathrm{U} / \mathrm{mL}$ penicillin, $100 \mu \mathrm{g} / \mathrm{mL}$ streptomycin, and $10 \%$ fetal calf serum (Flow Laboratories). Variants resistant to each of $\mathrm{ddC}, \mathrm{ddI}$ and 3TC that were selected under conditions of in vitro passage, as well as the HIV-IIIB laboratory strain of HIV-1 (supplied by Dr RC Gallo, National Institutes of Health, Maryland) were studied extensively (15). The HXB2-D clone of infectious DNA was used as a control for assaying the viral replication (19). Five micromolar ddC (Sigma Laboratories Inc, Missouri) was routinely used for propagation of viruses possessing a ddC-resistance phenotype (approximately 10-fold the usual 50\% effective concentration [EC50] for ddC-sensitive strains). Other procedures have been previously described $(14,15)$.

Viruses that had initially been grown in MT-4 cells were passaged onto phytohemagglutinin (PHA) prestimulated cord blood lymphocytes (CBL) (donated by the Department of Obstetrics of the authors' hospital) or peripheral blood mononuclear cells (PBMC) donated by healthy individuals (14). Samples of CBL or PBMC $\left(5 \times 10^{5}\right.$ cells $/ \mathrm{mL}$ ) were pretreated with concentrations of $\mathrm{ddC}$ between 0 and $50 \mu \mathrm{M}$ for $4 \mathrm{~h}$ and inoculated with CBL-grown HIV-1 at a multiplicity of infection of 1.0 (as determined by plaque assay on MT-4 cells), using the same concentration of drug as used for pretreatment. Fresh medium, containing $\mathrm{ddC}$ at appropriate concen- 
TABLE 1

Drug sensitivity of HIV-1 variants

\begin{tabular}{|c|c|c|c|c|c|}
\hline \multirow[b]{2}{*}{ Host cell } & \multirow[b]{2}{*}{ Variant } & \multicolumn{4}{|c|}{$\mathrm{EC}_{50}(\mu \mathrm{M})$} \\
\hline & & ddC & $3 \mathrm{TC}$ & ddl & AZT \\
\hline \multirow[t]{3}{*}{ MT-4 } & HXB2-D & 0.45 & 0.76 & 7.0 & 0.012 \\
\hline & HXB2-D184 & 2.5 & 1032 & 37.6 & 0.015 \\
\hline & HXB2-D65+184 & 5.8 & 1033 & 34.2 & 0.013 \\
\hline \multirow{3}{*}{$\begin{array}{l}\text { Cord blood } \\
\text { Iymphocytes }\end{array}$} & HXB2-D & 0.35 & 0.9 & 8.5 & 0.01 \\
\hline & HXB2-D184 & 1.8 & 552 & 26.5 & 0.02 \\
\hline & HXB2-D65+184 & 4.2 & 631 & 21.0 & 0.01 \\
\hline \multirow[t]{3}{*}{ PBMC } & HXB2-D & 0.4 & 0.7 & 6.4 & 0.02 \\
\hline & HXB2-D65 & 0.7 & 23.5 & 26.5 & 0.01 \\
\hline & HXB2-D184 & 0.6 & 478 & 5.7 & 0.02 \\
\hline
\end{tabular}

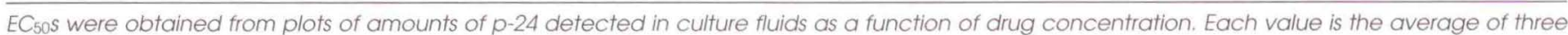
separate determinations ( \pm the standard mean deviation)

trations, was added three times per week along with fresh PHA prestimulated CBL. Similar studies were performed with ddI and 3TC at concentrations between 0 and $500 \mu \mathrm{M}$, and $\mathrm{AZT}$ at concentrations between 0 and $10 \mu \mathrm{M}$.

Cloning and sequencing: Cellular DNA was obtained from about $2 \times 10^{6}$ MT- 4 cells that had been infected with ddC-resistant variants of HIV-1 derived from HIV-IIIB by tissue culture selection as described (14). Polymerase chain reaction (PCR) methodology was used to amplify a 1742-bp segment containing the complete RT-coding sequence plus portions of the $3^{\prime}$ end of protease and the $5^{\prime}$ end of integrase (14).

Site-directed mutagenesis: The construction of mutated HXB2-D containing either the codon 65 (Lys $\rightarrow$ Arg) or 184 (Met $\rightarrow$ Val) mutations of the RT was as described to produce HXB2-D65 and HXB2-D184 (14). We also generated a recombinant that contained both these changes termed HXB2-D65 + 184. The presence of these substitutions was confirmed by DNA sequencing.

Transfections and viral resistance assays: MT- 4 cells were transfected by electroporation, and fresh MT-4 cells were added to cultures as soon as cytopathic effects were seen to generate viral stock. Culture fluids were clarified and frozen at $-70^{\circ} \mathrm{C}$ until study. Assays of HIV susceptibility to drugs, RT assays and p-24 antigen capture assays were performed as described (20). Viruses were isolated from patients on prolonged nucleoside therapy, using a protocol similar to that recently published (21), except that CBL were used in place of adult PBMC as HIV targets. Calculation of EC50 values was on the basis of p-24 antigen levels in culture fluids (14).

\section{RESULTS}

Cloning and sequencing of ddC-resistant HIV-IIIB, selected in tissue culture, revealed that mutations at codons 65 (Lys $\rightarrow$ Arg) and 184 (Met $\rightarrow$ Val) were frequently present. Similar findings were obtained using HIV-1 selected for resistance against ddI and 3TC under in vitro conditions.

Site-directed mutagenesis was employed to determine the potential biological significance of these mutations. Arg-encoding AGA was introduced in place of AAA at position 65 of the RT gene of HXB2-D to yield the recombinant clone HXB2-D65. In addition, a construct, HXB2-D65+184, was generated that contained both this change as well as the 184 alteration associated with high level resistance against 3TC and low level resistance against both ddI and ddC (14-16). Drug susceptibilities of each of these constructs were initially assessed by viral replication in MT-4 cells. EC50 values were determined from levels of p-24 antigen in culture fluids. Table 1 demonstrates that the AGA substitution at position 65 caused a significant diminution in susceptibility to both ddC and 3TC. However, HXB2D65+184 did not possess higher levels of drug resistance than those obtained with either mutation alone. Similar observations were obtained on the basis of RT levels in culture fluids as well as indirect immunofluorescence assays for p-24 antigen in infected cells (not shown).

Table 1 presents a summary of findings that show that the Arg-65 mutation caused a more than 10-fold loss in sensitivity to $\mathrm{ddC}$ and 20 -fold resistance against 3TC, without affecting sensitivity to AZT. A small degree of cross-resistance to ddI (approximately threefold) was also noted. In contrast, the site 184 mutation conferred resistance levels against 3TC of 500 to 1000 times, but only low level resistance (approximately fivefold) against each of ddI and ddC. Furthermore, certain of these resistance patterns were dependent on the host cell type used for each assay. While the site 65 mutation conferred resistance to both ddC and 3TC in each of MT-4 cells, CBL and PBMC, the site 184 mutation did not result in diminished sensitivity to ddI and ddC in PBMC. 
TABLE 2

Information on patients who received ddC

\begin{tabular}{|c|c|c|c|c|c|c|c|c|}
\hline \multirow{2}{*}{$\begin{array}{l}\text { Patient } \\
\text { number }\end{array}$} & \multirow{2}{*}{$\begin{array}{l}\text { Months } \\
\text { treated with } \\
\text { ddC }\end{array}$} & \multicolumn{2}{|c|}{ codon 65} & \multicolumn{2}{|c|}{$\begin{array}{l}\text { Genotype } \\
\text { codon } 184\end{array}$} & \multicolumn{2}{|c|}{ codon 69} & \multirow{2}{*}{$\begin{array}{c}\mathrm{EC}_{50} \text { fo } \\
\mathrm{ddC}\end{array}$} \\
\hline & & WT & mutated & WT & mutated & WT & mutated & \\
\hline 1 & 15 & + & + & + & - & + & - & 1.9 \\
\hline 2 & 7 & - & + & + & + & + & - & 1.6 \\
\hline 3 & 11 & + & + & + & - & + & - & 2.1 \\
\hline 4 & 6 & + & + & + & - & + & - & 5.3 \\
\hline 5 & 6 & + & - & + & + & + & - & 2.2 \\
\hline 6 & 0 & + & - & + & - & + & - & 0.4 \\
\hline 7 & 18 & + & - & + & + & + & - & ND \\
\hline 8 & 2 & + & - & + & - & + & - & 0.2 \\
\hline 9 & 10 & + & - & + & + & + & - & ND \\
\hline 10 & 0 & + & - & + & - & + & - & 0.4 \\
\hline 11 & 16 & + & - & + & - & + & - & 0.6 \\
\hline 12 & 5 & + & - & + & - & + & - & 0.2 \\
\hline 13 & 8 & + & - & + & - & + & - & ND \\
\hline
\end{tabular}

WT Wild-type: ND Not determined

Table 2 includes data on the therapeutic regimens received by $11 \mathrm{ddC}$-treated and two untreated patients, and the detection of resistance-conferring mutations as analyzed by PCR. All patients had received AZT for various times before changing to $\mathrm{ddC}$ for reasons of AZT intolerance or treatment failure. Pretreatment isolates from these individuals were not available. Viruses from patients whose cells contained the site 65 mutation were resistant to ddC, as determined in tissue culture CBL assays. The range of $\mathrm{EC}_{50}$ values for these isolates, ie, approximately five to 15 times above average, are consistent with previous studies on resistance to ddC (17). Sequencing of isolates from patients on prolonged ddC confirmed the presence of the site 65 mutation. All samples were also tested by PCR to detect the Val-184 substitution. Four samples possessed Val-184 and one possessed both Arg-65 and Val-184. None of the samples contained a previously described Asp-69 substitution.

\section{DISCUSSION}

HIV resistance to antiviral compounds has become an important issue, and is due to the infidelity of the HIV-1 RT and drug selection pressure. Mutations in the RT gene that encode resistance to each of AZT, ddI, ddC, 3TC and other drugs have been described (13-17). Sometimes, combinations of mutations may yield higher resistance levels than obtained with single mutations alone, while in other cases such combinations may help to restore sensitivity to AZT $(3,22)$.

We have shown that mutations at codon 65 (Lys $\rightarrow$ Arg) and 184 (Met $\rightarrow$ Val) are associated with HIV resistance to ddC and 3TC. A mutation responsible for resistance to ddC has been previously identified at codon 69 $(14,17)$. Interestingly, both the 65 and 69 mutations are located in the 65 to 70 amino acid sequence of the viral RT, known to be associated with the active site of this enzyme. Monoclonal antibodies against HIV RT enzymatic activity map to this region (23).

Both ddC and 3TC possess $2^{\prime}, 3^{\prime}$-dideoxy moieties, which may account for the cross-resistance between these drugs reported here. Consistent with this is that neither the Arg-65 nor Val-184 substitutions are present in HIV variants selected in AZT. A mutation at Val-74 that confers resistance against ddI and crossresistance to ddC has also been described (3).

HXB2-D, grown in CBL, continued to possess the codon 65 or 184 mutations and to maintain resistance to both ddC and 3TC. Hence, this mutation can persist in cells other than MT-4. However, resistance against ddC and ddI could no longer be detected when HXB2D 184 was grown in PBMC, indicating the host celldependent nature of some of these results. Patients whose isolates contained the ddC 65 mutation had all received therapy with ddC for at least six months. Similar results were obtained with each of 11 individuals, although an absence of the ddC 65 mutation was noted in seven other cases who also received prolonged ddC.

Since neither the Val-184 nor Arg-65 substitutions conferred resistance to AZT, these mutations may affect different regions of the RT. Lys-65 is on the 'fingers' subdomain of the RT crystal structure, thought to play a role in enzyme-template interaction, while Met-184 is on the 'palm' region related to primer-template binding activity (24). This may be why these two mutations, in concert, did not yield synergistic or antagonistic effects with regard to resistance to $\mathrm{ddC}$ and $3 \mathrm{TC}$.

We used specific PCR to amplify the Arg-65 substitution from clinical isolates obtained from 10 HIV-1 infected patients on prolonged ddC therapy. The site 65 mutation was present in each of four such individuals and absent in the other six. Of the four people who were positive for the Arg-65 codon, three contained viruses 
that were positive for the wild-type Lys-65 codon as well, while no mutations were seen with three control patients not treated with ddC over extensive periods. These data are consistent with observations of mixtures of quasi-species showing heterogeneity for viral mutation sites.

ACKNOWLEDGEMENTS: This research was supported by grants from Health and Welfare Canada and the Medical Research Council of Canada. We thank Ms F Busschaert for preparation of the manuscript.

\section{REFERENCES}

1. Larder B, Darby G, Richman DD. HIV with reduced sensitivity to zidovudine (AZT) isolated during prolonged therapy. Science 1989;243:1731-4.

2. Rooke R, Tremblay M, Soudeyns H, et al. Isolation of drug-resistant variants of HIV-1 from patients on long-term zidovudine (AZT) therapy. AIDS 1989;3:411-5.

3. St Clair MH, Martin JL, Tudor-Williams G, et al. Resistance to ddI and sensitivity to AZT induced by a mutation in HIV-1 reverse transcriptase. Science 1991:253:1557-9.

4. Larder BA, Coates KE. Kemp SD. Zidovudine-resistant human immunodeficiency virus selected by passage in cell culture. J Virol 1991;65:5232-6.

5. Gao Q. Gu Z, Parniak MA. Li X. Wainberg MA. In vitro selection of variants of human immunodeficiency virus type 1 resistant to 3 '-azido-3'-deoxythymidine and 2',3'-dideoxyinosine. J Virol 1992:66:12-9.

6. Nunberg JH, Schleif WA. Boots EJ, et al. Viral resistance to human immunodeficiency virus type 1-specific pyridinone reverse transcriptase inhibitors. J Virol $1991 ; 65: 4887-92$

7. Richman D, Shih C-K, Lowy I, et al. Human immunodeficiency virus type 1 mutants resistant to nonnucleoside inhibitors of reverse transcriptase arise in tissue culture. Proc Natl Acad Sci USA 1991:88:11241-5.

8. Tudor-Williams G, St Clair MH, McKinney RE, et al. HIV-1 sensitivity to zidovudine and clinical outcome in children. Lancet 1992;339:15-9.

9. Montaner JSG, Singer J, Schechter MT, et al. Clinical correlates of in vitro HIV-1 resistance to zidovudine. Results of the Multicentre Canadian AZT trial. AIDS 1993:7:189-96.

10. Kozal MJ, Shafer RW, Winters MA, Katzenstein DA, Merigan TC. A mutation in human immunodeficiency virus reverse transcriptase and decline in CD4 lymphocyte numbers in long-term zidovudine recipients. $\mathrm{J}$ Infect Dis 1993; 167:526-32.

11. Furman PA, Fyfe JA, St Clair MH, et al. Phosphorylation of 3 '-azido-3'-deoxythymidine and selective interaction of the $5^{\prime}$-triphosphate with human immunodeficiency virus reverse transcriptase. Proc Natl Acad Sci USA 1986:83:8333-7

12. Preston BD. Poiesz Bu, Locb LA. Fidelity of HIV-1 reverse transcriptase. Science 1988:242:1168-71.

13. Larder BA, Kemp SD. Multiple mutations in HIV- 1 reverse transcriptase confer high-level resistance to zidovudine (AZT). Science 1989:246:1 155-8.

14. Gu Z, Gao Q. Li X, Parniak MA, Wainberg MA. Novel mutation in the human immunodeficiency virus type 1 reverse transcriptase gene that encodes cross-resistance to $2^{\prime}, 3^{\prime}$-dideoxyinosine and $2^{\prime}, 3^{\prime}$-dideoxycytidine. J Virol 1992:66:7128-35.

15. Gao Q. Gu Z, Parniak MA, et al. The same mutation that encodes low-level human immunodeficiency virus type 1 resistance to $2^{\prime} 3^{\prime}$-dideoxyinosine and $2^{\prime} 3^{\prime}$-dideoxycytidine confers high-level resistance to the

(-) enantiomer of $2^{\prime}, 3^{\prime}$-dideoxy-3'-thiacytidine. Antimicrob Agents Chemother 1993:37:1390-2.

16. Shinazi RF, Lloyd RM Jr. Nguyen M-H, et al. Characterization of human immunodeficiency viruses resistant to oxathiolane-cytosine nucleosides. Antimicrob Agents Chemother 1993;37:875-81.

17. Fitzgibbon JE, Howell RM, Haberzettle CA. Sperber SJ. Gocke DJ, Dubin DT. Human immunodeficiency virus type 1 pol gene mutations which cause decreased susceptibility to $2^{\prime}, 3^{\prime}$-dideoxycytidine. Antimicrob Agents Chemother 1992:36:153-7.

18. Meng T-C, Fishl MA. Boota MM, et al. Combination therapy with zidovudine and didexoycytidine in patients with advanced human immunodeficiency virus infection. A phase I/II study. Ann Intern Med 1992; 116:13-20.

19. Fisher AG, Collalti E, Ratner L, Gallo RC, Wong-Staal F. A molecular clone of HTLV-III with biological activity. Nature 1985;316:262-5.

20. Rooke R, Tremblay M. Wainberg MA. AZT (zidovudine) may act postintegrationally to inhibit generation of HIV-1 progeny virus in chronically infected cells. Virology 1990; 176:205-15.

21. Japour AJ, Mayers DL, Johnson VA, et al. Standardized peripheral blood mononuclear cell culture assay for determination of drug susceptibilities of clinical human immunodeficiency virus type 1 isolates. Antimicrob Agents Chemother 1993;37:1095-101.

22. Tisdale M. Kemp SD. Parry NR. Larder BA. Rapid in vitro selection of human immunodeficiency virus type 1 resistant to 3 -thiacytidine inhibitors due to a mutation in the YMDD region of reverse transcriptase. Proc Natl Acad Sci USA 1993:90:5653-6.

23. Wu J, Amandoron E, Li X, Wainberg MA. Parniak MA. Monoclonal antibody-mediated inhibition of HIV-1 reverse transcriptase polymerase activity. J Biol Chem 1993;268:9980-5.

24. Kohlstaedt LA, Wang J, Friedman JM, Rice PA, Steitz TA. Crystal structure at $3.5 \AA$ resolution of HIV-1 reverse transcriptase complexed with an inhibitor. Science 1992;256: 1783-90. 


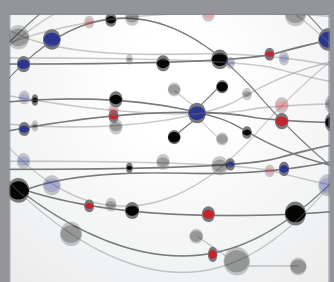

The Scientific World Journal
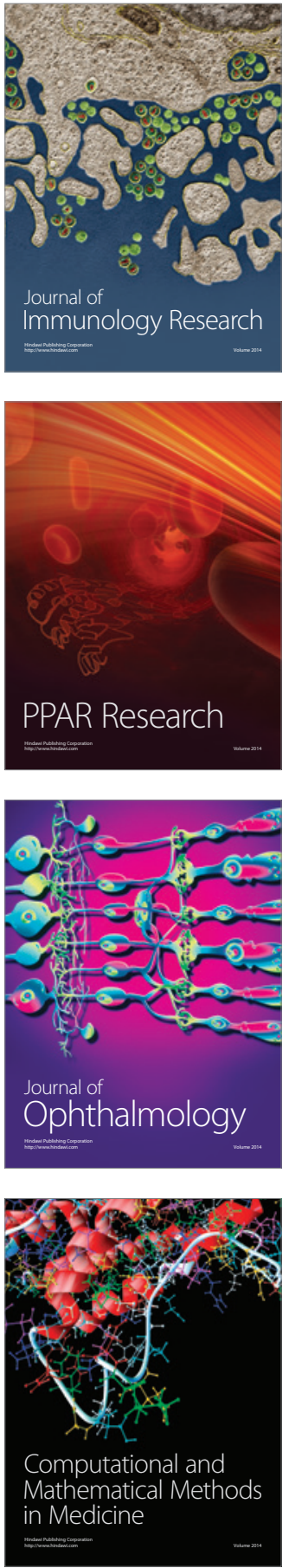

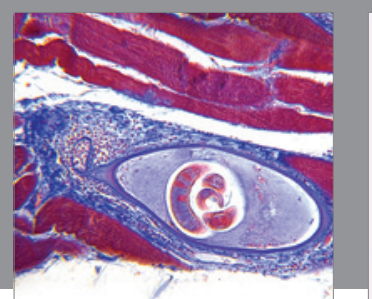

Gastroenterology Research and Practice

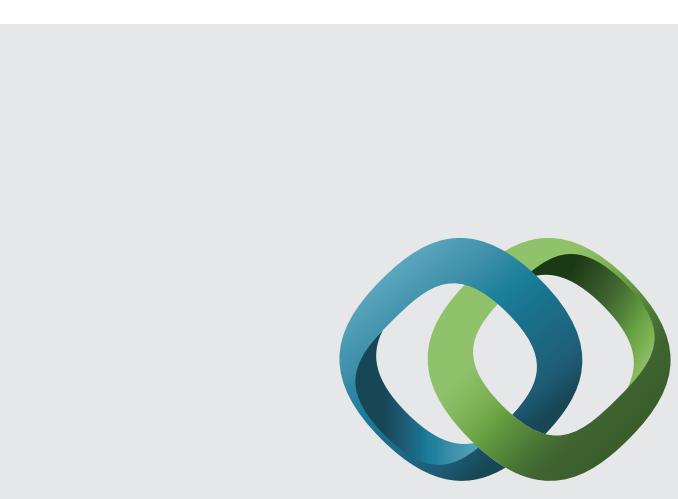

\section{Hindawi}

Submit your manuscripts at

http://www.hindawi.com
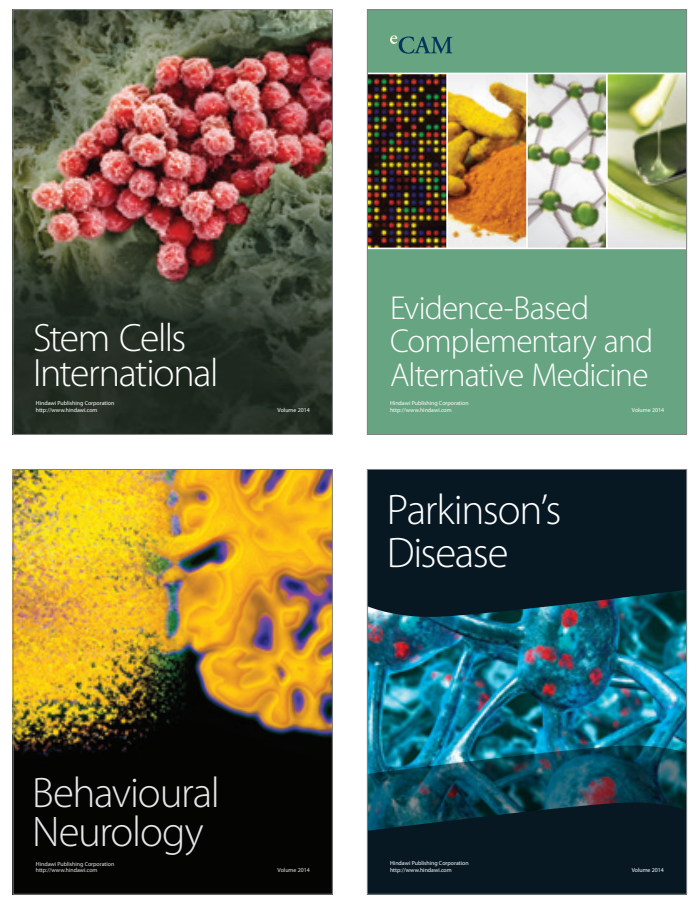
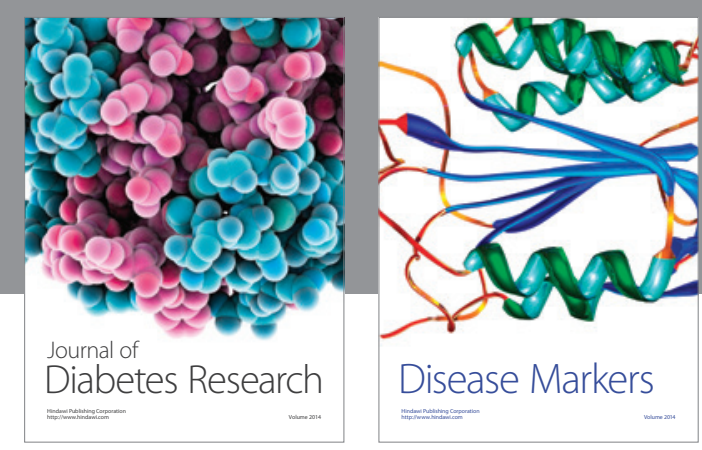

Disease Markers
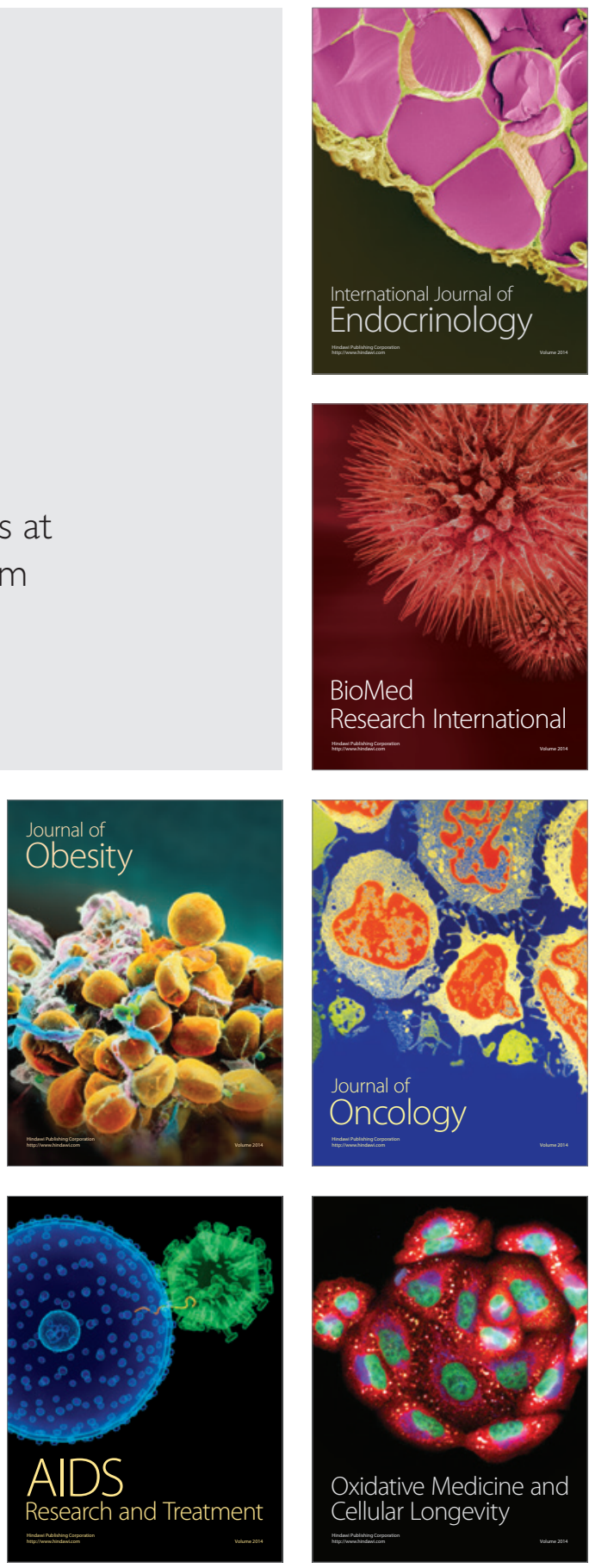